GLOBAL WATER PATHOGEN PROJECT

PART FIVE. CASE STUDIES

\title{
BUILDING A SAFE RECYCLED WATER SCHEME
}

\author{
Annalisa Contos \\ Atom Consulting \\ Sydney, Australia \\ Andrew Francis \\ Parkes Shire Council \\ Parkes, Australia \\ Julian Fyfe \\ Parkes Shire Council \\ Parkes, Australia
}




\section{Copyright:}

\section{cc) (1) (2) \\ BY SA}

This publication is available in Open Access under the Attribution-ShareAlike 3.0 IGO (CC-BY-SA 3.0 IGO) license (http://creativecommons.org/licenses/by-sa/3.0/igo). By using the content of this publication, the users accept to be bound by the terms of use of the UNESCO Open Access Repository (http://www.unesco.org/openaccess/terms-use-ccbysa-en).

\section{Disclaimer:}

The designations employed and the presentation of material throughout this publication do not imply the expression of any opinion whatsoever on the part of UNESCO concerning the legal status of any country, territory, city or area or of its authorities, or concerning the delimitation of its frontiers or boundaries. The ideas and opinions expressed in this publication are those of the authors; they are not necessarily those of UNESCO and do not commit the Organization.

\section{Citation:}

Contos, A., Francis, A. and Fyfe, J. (2019). Building a safe recycled water scheme. In: J.B. Rose and B. JiménezCisneros, (eds) Water and Sanitation for the 21st Century: Health and Microbiological Aspects of Excreta and Wastewater Management (Global Water Pathogen Project). (S. Petterson and G. Medema (eds) Part 5: Case Studies), Michigan State University, E. Lansing, MI, UNESCO. https://doi.org/10.14321/waterpathogens.75

Acknowledgements: K.R.L. Young, Project Design editor; Website Design: Agroknow (http:// www.agrøknow.com)

Last published: May 13, 2019 


\section{Summary}

\section{Highlights}

- An application of the Australian Guidelines for Wastewater Recycling (2006) is presented

- Shows the design and operation of a fit for purpose recycling scheme

- Project driven by a need for climate resilient water sources, improved green spaces, low carbon water and resilient infrastructure.

- The end use was municipal irrigation, higher exposure uses such as car wash and ecogardens were rejected

- Chlorination and UV were selected from available technologies to meet these targets

- Designer and operator engagement ensured on-line monitoring of chlorine and UV provided control

- Shows how pathogen removal targets define design criteria for recycled water plants

\section{Management objective}

The objective of this case study was to:

- determine the required pathogen reductions for the reuse of effluent for irrigation of sports fields, golf course and community open spaces.

- Select and design the appropriate process units to achieve the necessary pathogen reduction.

\section{Location and setting}

The town of Parkes is located in central NSW, approximately $400 \mathrm{~km}$ west of Sydney. The town of 12,000 undertook an upgrade of their sewage treatment system. As part of this project Parkes Shire Council (PSC) has been exploring opportunities to recycle water throughout the town. A recycled water strategy explicitly mapped the links between the SDGs including climate resilient water supplies, improved green spaces, low carbon water and resilient infrastructure.

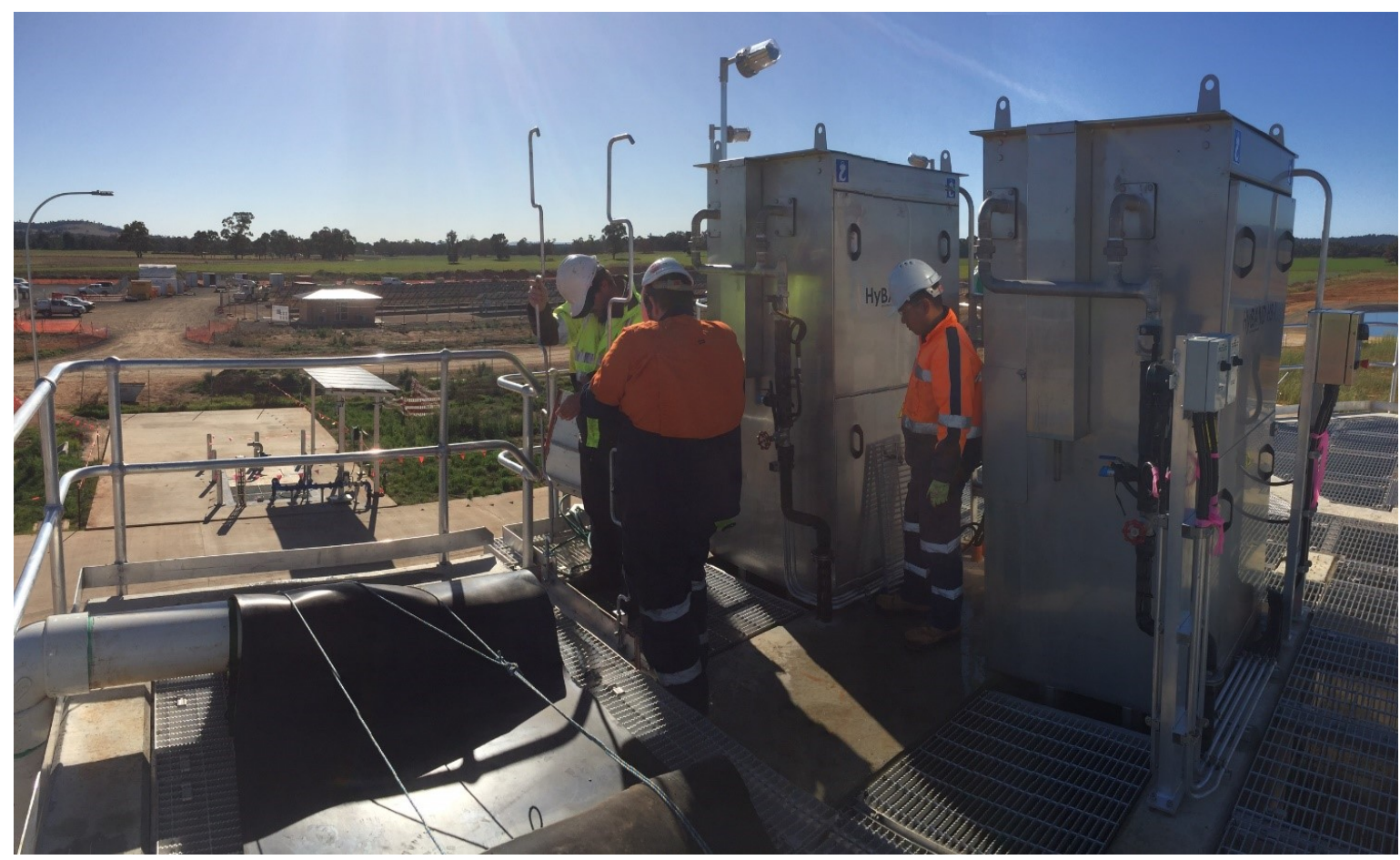

Figure 1. Commissioning of the upgraded STP (photo provided by Annalisa Contos) 


\section{Description of the system}

Parkes Shire Council analysed water sources and use options to optimise the supply and demand of water throughout the town to maintain industry, urban green spaces and supply potable water. An integrated water management study investigated options including stormwater, recycled water, bore, dam and river water. The preferred option for recycled water was to use it for irrigation of community open spaces including golf course, horse racetrack and sports fields. Higher exposure uses such as commercial car wash and schools (including ecogardens) were considered but not selected in the strategy due to their higher treatment requirements and low demands.

Pathogen reduction values for municipal irrigation were selected from the Australian Guidelines for Water Recycling (AGWR, 2006 - see case study 3.2). Considering exposure to facility users and the community the required $\log _{10}$ reduction value for campylobacter of 3.7, rotavirus of 5.2 and Cryptosporidium of 4.0 were determined.

Having established the pathogen reduction requirements, a range of technology combinations including membrane, UV and chlorination were evaluated to meet these requirements. By determining the end users prior to the recycled water plant design, pathogen reduction targets could be explicitly established and unit processes selected to specifically meet the required pathogen reductions.

\section{Outcome and recommendations}

A multi-disciplinary team including designers, operators, managers and a water quality specialists team engaged in a series of facilitated risk workshops covering process risk, water quality risks, constructability, operability and maintainability.

In addition to secondary treatment, chlorination and UV were selected to achieve the required removals. Chlorination was designed to achieve a minimum $4 \log _{10}$ reduction of virus and bacteria. UV was designed to achieve $4 \log _{10}$ reduction of Cryptosporidium and $2 \log _{10}$ virus (Adenovirus Type 40).

Real-time monitoring parameters of chlorine contact time and UV dose were selected to monitor the critical control points necessary to assure recycled water safety.

\section{Implications for practioners}

Understanding the end user requirements for the recycled water allowed pathogen reduction targets to be established at the project outset. The treatment train could then be selected to efficiently and effectively meet these targets.

The multidisciplinary team, including operator involvement in design provides a high confidence that the plant can both treat the water safely and provide the operations staff with real-time information on water safety.

\section{Introduction}

This project took place in Parkes in central New South Wales (NSW), Australia. The local government, Parkes Shire Council (PSC), undertook an integrated water cycle management study to optimise investment in water cycle infrastructure to meet community expectations. The study analysed water sources and use options to optimise the supply and demand of water throughout the town to maintain industry, urban green spaces and supply potable water. The sources investigated included stormwater, recycled water, bore (groundwater), dam (reservoir) and river water. The preferred option for recycled water was to use it for irrigation of community open spaces including golf course, horse racetrack and sports fields. Higher exposure uses such as commercial car wash were considered but not selected in the strategy due to their higher treatment requirements and low demands. The recycled water plant was then designed to provide operation information to continually demonstrate it was producing fit for purpose recycled water.

\section{Problem formulation}

The overall objectives of the project were to strengthen water security and drought resilience for Parkes by:

- providing an additional, climate-resilient water source;

- reducing demand for potable water; and

- addressing Parkes' remoteness from raw water sources.

Additional project goals included:

- Maintaining and improving community services and amenity by

1. ensuring green parks and sports fields through drought; and

2. adopting innovative approaches to water service provision.

- Economic stimulus by supporting, and promoting population, business, employment and tourism growth.

- Reducing the energy footprint of Parkes' water supply to guard against rises in power prices and reduce Council's greenhouse gas emissions.

In order to achieve these goals it was necessary to:

- Determine the suitable level of pathogen reduction required to safety use sewage effuent for irrigation of sports fields, golf course and community open spaces.

- Select and design of the appropriate process units to achieve the necessary pathogen reduction

- Ensure appropriate process control for the safe supply of recycled water 


\section{Approach}

A recycled water strategy was developed which mapped out the project approach, design criteria and project constraints. The strategy not only considered water quality but also issues associated with available supply vs end user demands, environmental requirements, and project legal approvals. Key aspects considered in the recycled water strategy are listed in Table 1.

\section{Table 1. Recycled water strategy}

\begin{tabular}{lr}
\hline Aspect & Considerations \\
\hline $\begin{array}{l}\text { Project drivers, objectives and } \\
\text { goals }\end{array}$ & International (e.g.SDGs), national and local drivers \\
$\begin{array}{l}\text { Governance and administration } \\
\text { Recycled water scheme } \\
\text { components }\end{array}$ & $\begin{array}{c}\text { Approvals, stakeholders, fiscal governance, project risk management } \\
\text { considerations, quantity and quality requirements, energy efficiency), distribution and } \\
\text { storage }\end{array}$ \\
$\begin{array}{l}\text { Project assessment process } \\
\text { Environmental, social and governance, technical and economic aspects of the project to } \\
\text { be evaluated were documented. These criteria were developed through an earlier } \\
\text { community engagement process. }\end{array}$ \\
$\begin{array}{c}\text { Cigh level sizing, treatment technologies, storage and treatment options were } \\
\text { considered. }\end{array}$
\end{tabular}

The strategy outlined a series of work packages (WP) and their linkages to be completed as part of the project
(Figure 2).

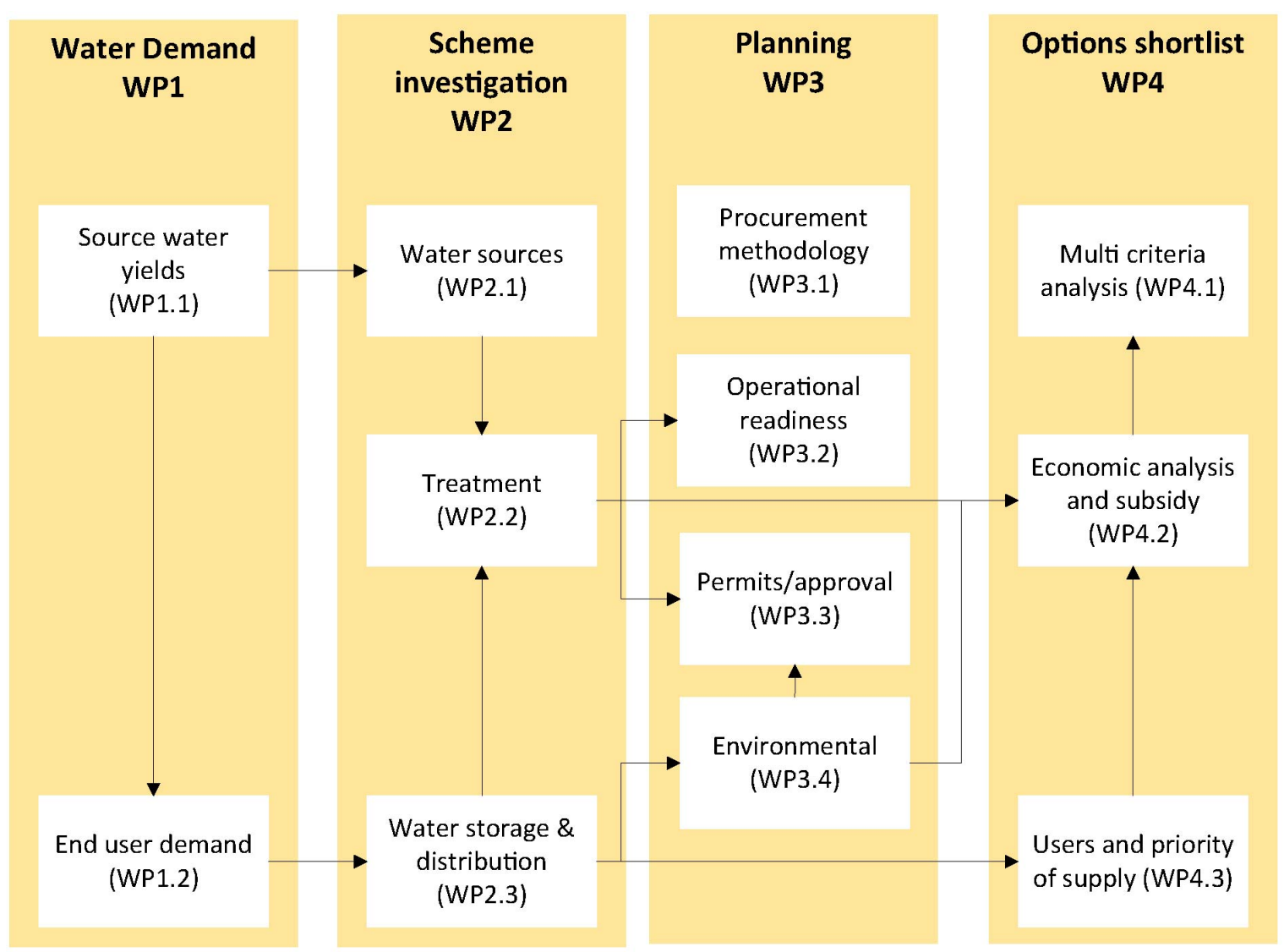

Figure 2. Work packages (WP) identified in the Parkes' Recycled Water Strategy (figure provided by Parkes Shire Council with permission) 


\section{End use water quality requirements}

The strategy established that recycled water would be used for the irrigation of open spaces including council . operated facilities and those operated by community groups (a golf course and race course). Planned and incidental exposures that were considered are outlined in Table 2

\section{Table 2. Planned and incidental exposures}

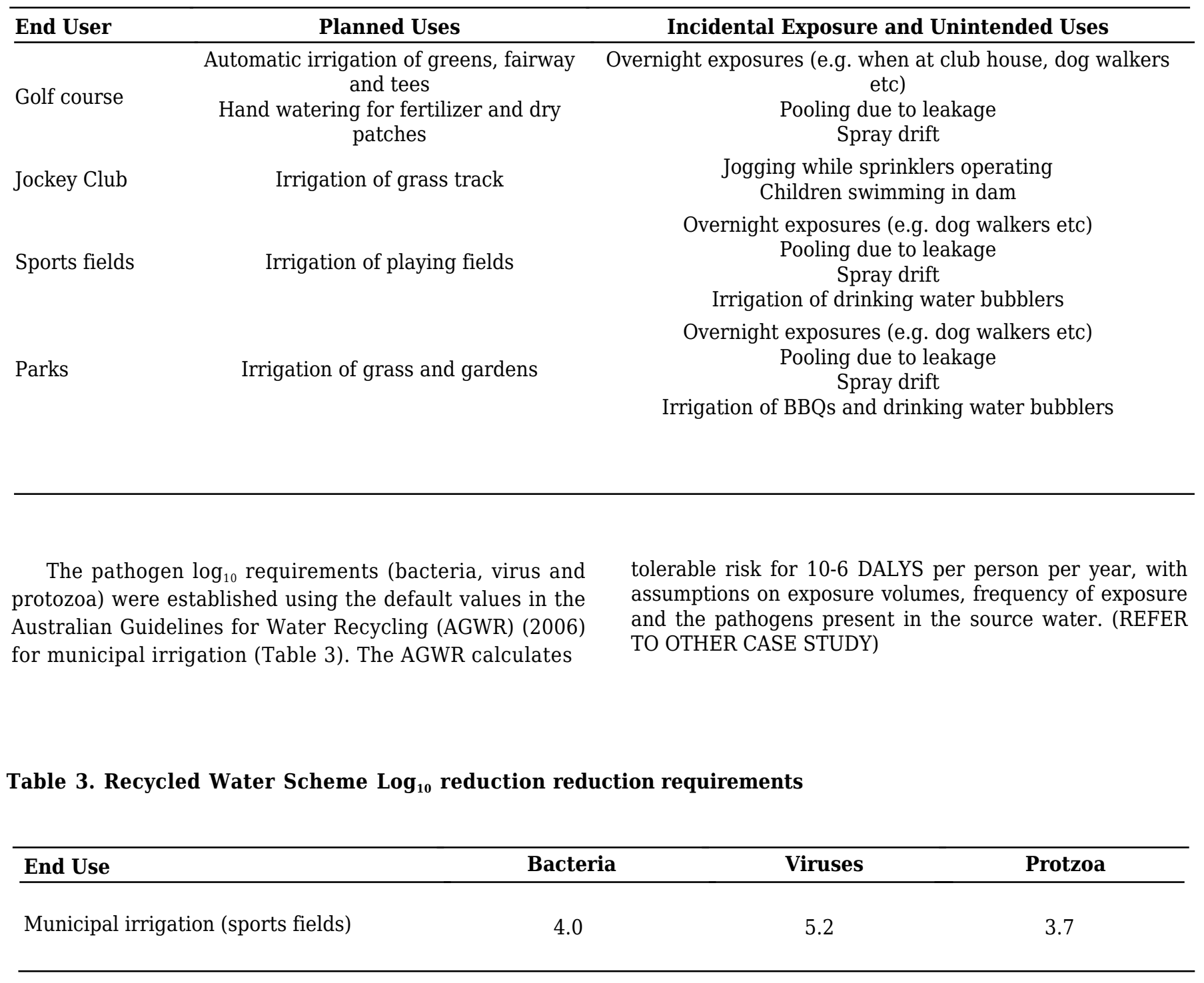

\section{Using a multi-disciplinary team}

A multi-disciplinary team was involved in the project from concept through to delivery. The team included both internal and external stakeholders. Project stakeholders were identified at the project conception. External stakeholders included the regulators (health, infrastructure and environmental regulators) and community (organisations using the recycled water, sporting groups) and internal stakeholder (operators, supervisors, managers, senior staff and councillors).
In developing the project documentation, PSC was careful to encourage and facilitate co-operation across the various professional disciplines involved in the preparation of that documentation. Central to this was the principle of taking a 'whole of team' approach to project documentation. By taking this approach PSC was able to ensure consistency in commercial and technical risks 
across all project documentation, and to ensure that contractual provisions were drafted in a manner that facilitated the outcomes being driven by the technical documentation.

\section{Risk approach}

Risk workshops were embedded throughout the project design phase. Initial workshops considered the appropriate technologies to manage the water quality risks. As the design progressed hazard and operability workshops (HAZOPs) and construction hazard and implication review (CHAIR) workshops were undertaken. The HAZOP workshops considered how the proposed design might be operated in an unintended manner. The workshops consider whether there was sufficient redundancy in instruments and how the operators would become aware of plant faults. The CHAIR workshop considered the construction and maintenance of the plant. The PSC recognised that equipment needs to be easy to maintain for it to continue functioning as intended. Each of the workshop outcomes was fed back into the design. The workshops also served to familiarise the plant operators with the proposed plant and upskill them in the proposed plant operation. Water quality risk assessment workshops were conducted at the concept and detailed design phase. These workshops focussed on the design and operation of the unit processes and the instrumentation and SCADA control and recirculation loops required to identify and manage water that was not fit for purpose (i.e. off spec).

\section{The design approach}

At all stages through the design, the focus was on preventative risk management - how to ensure the water the recycled water plant produced would always meet the required $\log _{10}$ reduction values and that the operators had sufficient flexibility so that unsafe water could be detected via operational surrogates and diverted. Diversion pathways were provided for off spec water coming from secondary treatment, UV, chlorination and storage.

PSC selected UV disinfection and chlorination to achieve the required pathogen $\log _{10}$ reductions. Council evaluated the use of membranes as a treatment barrier, however they were not selected as UV and chlorination had a lover resource footprint. The design $\log _{10}$ reductions are shown in Table 4.

Table 4. Design $\log _{10}$ reductions for the Parkes Recycled Water System

\begin{tabular}{lccc}
\hline Process & Protozoa & Virus & Bacteria \\
\hline Secondary treatment & 0.0 & 0.0 & 0.0 \\
UV disinfection & 4.0 & 2.0 & 4.0 \\
Chlorination & 0.5 & 4.0 & 4.0 \\
Total Design Recycled Water LRVs & 4.5 & 6.0 & 8.0 \\
Municipal Irrigation LRVs (required) & 3.7 & 5.2 & 4.0
\end{tabular}

Table 5. System design

Element
$\begin{aligned} & \text { Raw sewage is received from the Parkes sewerage network. All sewage is pumped to the STP through a } \\ & \text { pump station. The pump station can deliver two flows; } 180 \mathrm{~L} / \mathrm{s} \text { and } 230 \mathrm{~L} / \mathrm{s} \text {, depending upon influent } \\ & \text { flows. The STP can also accept septage. Operators are present during septage delivery and initiate the } \\ & \text { transfer of septage from the septage receival area to the inlet works. }\end{aligned}$
The sewage treatment plant (STP) provides tertiary treatment with up to 15,000 equivalent persons
(EP) capacity.
$\begin{aligned} & \begin{array}{l}\text { Treatment } \\ \text { overview }\end{array} \\ & \text { Raw sewage passes through screening and grit removal, intermittently decanted extended aeration } \\ & \text { (IDEA), multi-point alum dosing for phosphorous removal and clarification. Effluent to be released to } \\ & \text { the environment is disinfected with UV. Effluent for reuse is diverted after the clarifier to the recycled } \\ & \text { water plant. The recycled water plant consists of disc filtration to reduce suspended solids, UV and gas } \\ & \text { chlorine disinfection. }\end{aligned}$


Element

Primary

Secondary

Recycled Water Plant

Distribution and storage

Effluent

discharge

\section{Description}

The screening process is achieved through 2 band screens (with a bar screen bypass). Screened water then passes through to the grit removal chamber. Sewage exits the grit removal chamber and passes into a vortex discharge channel. From the vortex discharge channel sewage passes through a splitter which separates the flow into two process streams.

Two process streams operating in parallel undergo secondary treatment through IDEA. Multi stage alum dosing is available to achieve the required phosphorous removal. Sodium hydroxide dosing is dosed upstream of the IDEA for $\mathrm{pH}$ control.

The recycled water plant is designed to minimise its carbon footprint. There are two operating windows, one during peak solar production and the other during off-peak. Water to be recycled is stored in the recycled water feed storage lagoon (4ML floating cover) to provide feed water during these periods. The design flowrate for the recycled water plant is $36 \mathrm{~L} / \mathrm{s}$.

The recycled water plant pump station transfers the secondary treated water to three Amiad disc filters (nominal $20 \mu \mathrm{m}$ filter pore size) operating in parallel to pre-screen the UV feed water.

An in-line pressure UV unit is used for UV disinfection. The unit was selected to provide a minimum dose of $100 \mathrm{~mJ} / \mathrm{cm} 2$ to achieve a $2 \log$ reduction of Adenovirus Type 40. This unit was pre-validated for UVTs from $45 \%$ (dependent upon feed rate).

Chlorine contact is achieved through a chlorine contact pipe. C.t is $20 \mathrm{mg}$.min/L to achieve a $4 \mathrm{LRV}$ of Coxsackie B5 virus (Keegan 2012).

After primary disinfection, the water is stored in a recycled water storage tank prior to distribution to end users. Recycled water is stored in dams and tanks on the end users sites prior to use.

Effluent to be released to the environment is disinfected with UV.

A process flow diagram is shown in Figure 3.

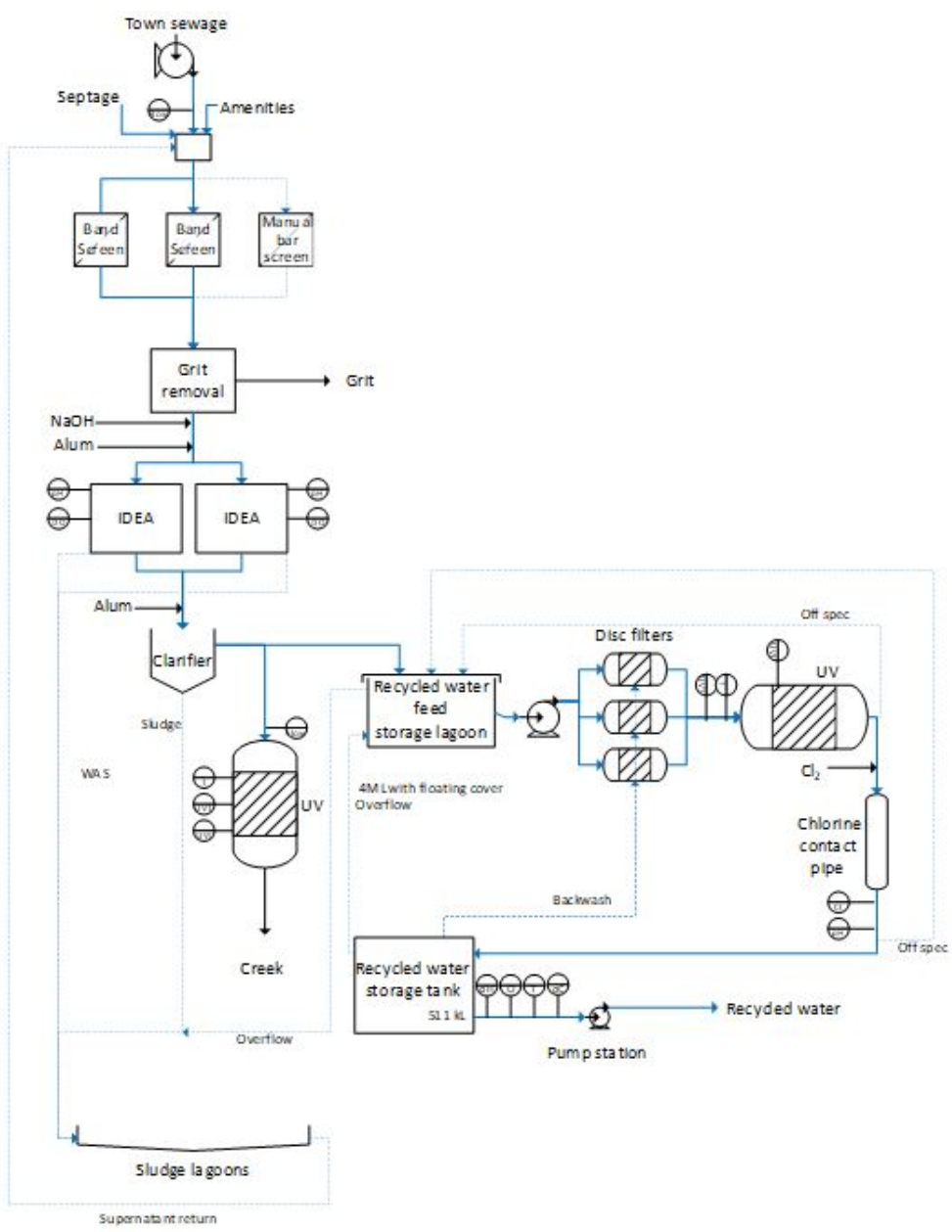

Figure 3. Process flow diagram for Parkes Water Recycling Plant (figure provided by Parkes Shire Council with permission) 
An important aspect of the design is the ability to divert water to environmental discharge if it outside the treatment design envelope. The preventative risk approach was to establish 'gates' termed critical control points through which the water would not pass into the next stage of the recycled water system unless it was of suitable quality. The critical control points have associated real-time monitoring parameters. These parameters have a critical limit which if exceeded will divert the water to be re-processed or discharged to the environment. The system critical control points, their monitoring parameters and associated actions are summarised in Table 6. This preventative approach demonstrates leading practice in recycled water treatment.

Table 6. Critical Control Points (CCPs)

\begin{tabular}{lcccc}
\hline Step (CCP) & Monitoring Parameter & Critical Limit & Action & Basis \\
\hline UV & UV dose & 2 @ 45\% UVT & $\begin{array}{c}\text { Redirect water to recycled } \\
\text { water feed lagoon }\end{array}$ & 2 LRV of adenovirus \\
Chlorination & $\begin{array}{c}\text { Calculated C.t (based on post } \\
\text { chlorination free chlorine and } \\
\text { flow) }\end{array}$ & $>8.0$ & $\begin{array}{c}\text { Redirect water to recycled } \\
\text { water feed lagoon }\end{array}$ & $\begin{array}{c}\text { 4 LRV Coxsackie B5 } \\
\text { virus }\end{array}$
\end{tabular}

The multi-disciplinary team worked with the regulators to consider start-up scenarios when the free chlorine residual may be low but primary kill was still achieved. The multi-disciplinary team agreed to the following scenarios:

- For a recycled water plant start up following a routine shutdown, where there is a measurable free chlorine residual at the chlorine contact pipe outlet the plant should shutdown again if C.t has not been achieved within 3 volumes of the chlorine contact pipe.

- For an AWRF start up following a chlorination CCP breach shutdown - Divert to waste from outlet of chlorine contact pipe until C.t achieved.

- For a recycled water plant start-up start up following a short shutdown (days-weeks), where there is no measurable free chlorine residual at the chlorine contact tank outlet, the recycled water plant should divert to waste from outlet of chlorine contact pipe until C.t achieved.

- For an AWRF start up following a long shutdown (months), where there is not a measurable free chlorine residual at the chlorine contact pipe the recommissioning process should be developed.

\section{Capacity building}

Council also identified that up-skilling its own operators would be essential to the safe operation of the plant. When
PSC commenced the planning processes for the design, construction and commissioning of the STP, the need to build capacity within the existing water team and hire for the skills the new STP required was identified. PSC took a 5-pronged approach to this challenge:

1. Internal start-up process principles

2. Building operators capacity to input into design

3. Select staff for new skills

4. Train operators

5. Develop systems to remove error

\section{Implications for practitioners}

This project demonstrated the importance of early identification and documentation of the project's objectives, drivers and context. By undertaking the recycled water strategy and identifying internal and external stakeholders, a holistic design could be developed - one that provides safe irrigation water as well as meeting community needs and regulatory requirements.

The multi-disciplinary approach to the project is a key for in its success. Engagement of end users and regulators from the project's development has meant Council understands stakeholders needs and limitations. These were documented in the early stages of the process and incorporated into the design. This early work has reduced the need for later changes, which become more costly as the project progresses. Upskilling of operational staff through the design phases has allowed additional monitoring, operability and maintainability aspects to be 
incorporated in to the plant design.

Design of water recycling plants should consider

- critical control points

- surrogates for water safety at points that can be monitored in real time

- diversion loops for each process step

\section{Implication for risk management}

This project demonstrates how a preventative risk management approach can be implemented for the design of a new water recycling scheme. The recycled water strategy documented the project risks and their management as shown in Table 7.

Table 7. Identified project risks

\begin{tabular}{|c|c|}
\hline Risk Area & Management \\
\hline Project construction risks & $\begin{array}{c}\text { Project was considered Strategic Project, oversighted by senior staff through the project } \\
\text { management steering committee } \\
\text { A broad-brush risk assessment was used to manage the project risks }\end{array}$ \\
\hline Environmental risks & $\begin{array}{l}\text { Management of environmental risks (both construction and on-going operation) was } \\
\text { considered as will require consideration as part of the options development. }\end{array}$ \\
\hline Transitional risks & $\begin{array}{c}\text { Risks associated with transition the scheme from a construction project to an operational } \\
\text { asset were considered. This included considerations of: } \\
\cdot \text { Asset operation } \\
\cdot \text { Skill requirements } \\
\cdot \text { Staffing requirements } \\
\cdot \text { Operations and maintenance requirements } \\
\cdot \text { Record keeping }\end{array}$ \\
\hline Operational risks & $\begin{array}{l}\text { Operational risks (including water quality) needed to be considered throughout the planning } \\
\text { phases and were evaluated as part of the multicriteria analysis. }\end{array}$ \\
\hline
\end{tabular}
phases and were evaluated as part of the multicriteria analysis.

Through the design phase of the project, multi-disciplinary

professional facilitated workshops (Table 8) were held using industry standard frameworks to improve the design, operation and maintenance of the recycled water plant.

Table 8. Risk workshops to improve management of water quality

\begin{tabular}{lc}
\hline Workshop & Risk Area \\
\hline $\begin{array}{l}\text { HAZOP (Hazard and } \\
\text { operability) }\end{array}$ & $\begin{array}{r}\text { Considered how deviations in plant operation from } \\
\text { the design intent may occur }\end{array}$ \\
$\begin{array}{l}\text { CHAIR (Construction } \\
\text { hazard and implication } \\
\text { review) }\end{array}$ & $\begin{array}{c}\text { Considered the safe construction, commissioning, } \\
\text { maintenance (including instrumentation) and future } \\
\text { demolition of the plant }\end{array}$ \\
& $\begin{array}{l}\text { Identifies and prioritises hazards and risks, } \\
\text { identifies the control measures in place for } \\
\text { addressing the identified hazards and risks and } \\
\text { considered any additional controls or actions that } \\
\text { may be required to improve the risk management of } \\
\text { assessment } \\
\text { the scheme. }\end{array}$ \\
& $\begin{array}{c}\text { Multiple workshops may be necessary to ensure the } \\
\text { risk analysis consider the current design and } \\
\text { operation of the scheme. }\end{array}$
\end{tabular}

\section{Typical Attendees}

Plant designers, PSC plant operators, PSC managers, independent subject matter expects, workshop facilitator

Plant designers, PSC plant operators, PSC managers, independent subject matter expects, workshop facilitator

Plant designers, PSC plant operators, PSC managers, independent subject matter expects, public health and infrastructure regulators workshop facilitator 